\title{
Archives and its Role in Preserving the Nation Memory: Legal and Scientific Use of the Records and the Role of National Records and Archives Authority in Oman as a Model
}

\author{
ABDULMOHSIN SAID AL HINAI \\ Director General of Records Organization, National Records and Archives Authority - NRAA - Oman \\ e-mail: abdulm@nraa.gov.om
}

Archives and its Role in Preserving the Nation Memory: Legal and Scientific Use of the Records and the Role of National Records and Archives Authority in Oman as a Model

\section{ABSTRACT}

The history of archives is very old. Thousands of clay tablets dating into to the third and second millennium B.C were found in cities such as Elba, Syria (2350 B.C.). These archives have been fundamental for understanding ancient alphabets, languages, culture, political and social structure prevailing in those time. Archives were established by the Church from the fifth century and are kept till nowadays. People started to register and record their activity and events, in the rocks, animal bones and skin. Archives play an important role in the nation memory. Archives and records are important for organizations, individuals and the community. They give and provide us an evidence and information about past events and actions. Record keeping has a long history in different civilization, and archives transfer to us the evaluation of the human mind and the understanding of different events during the history, like the collapse of civilization, boundaries dispute, wars that decimated the humans... Archives collect original unpublished material or primary sources; these records are unique and irreparable. If an archival record is damaged, stolen or exposed to various dangers such as wars and terrorist attacks, the information it contains is lost forever. Archives can be an incredibly rich holder of information that should be kept according to legislation and regulations in favour of the archive staff or its clients and should enable the scientific, legal and public use of preserved archival records. This paper will describe in brief these uses and reflect to National Records and Archives Authority in Oman as example.

Key words: National Records and Archives Administration, Sultanate of Oman, scientific use, legal use, public use, archival processing

Gli archivi ed il loro ruolo nel preservare la memoria della nazione: uso legale e scientifico dei documenti ed il ruolo dell'Autorità Nazionale per i Documenti e gli Archivi dell'Oman come modello

\section{SINTESI}

La storia degli archivi è molto antica. Migliaia di tavolette d'argilla risalenti sin al terzo e secondo millennio a.C. sono stati trovati in città come Elba, Siria (2350 a.C.). Questi archivi sono stati fondamentali per la comprensione degli alfabeti antichi, delle lingue, della cultura, della struttura politica e sociale di quei tempi. Archivi sono stati costituiti dalla Chiesa a partire dal V secolo e si sono conservati fino ad oggi. Si è iniziato a registrare attività ed eventi nelle rocce, nelle ossa di animali e su pelle. Gli archivi svolgono un ruolo importante nella memoria della nazione. Gli archivi e le registrazioni sono importanti per le organizzazioni, gli individui e la comunità. Danno e forniscono prova ed informazione su eventi ed azioni passate. La tenuta dei registri ha una lunga storia nelle diverse civiltà, e gli archivi ci riportano la valutazione della mente umana e la comprensione dei diversi eventi nel corso della storia, così come il crollo della civiltà, i termini delle controversie, le guerre che hanno decimato l'umanità... Gli archivi raccolgono materiale originale inedito o fonti primarie; questi documenti sono unici e irreparabili. Se un documento archivistico è danneggiato, rubato o esposto a diversi pericoli come guerre ed attacchi terroristici, le informazioni che contiene sono perduti per sempre. Gli archivi possono essere un contenitore incredibilmente ricco di informazioni, che dovrebbe essere tenuto in conformità alle disposizioni di legge ed ai regolamenti in favore del personale dell'archivio o alla sua utenza e dovrebbe permettere l'utilizzo scientifico, giuridico e pubblico dei documenti archivistici conservati. Il presente articolo descrive in breve questi usi portando l'esempio dell'Autorità Nazionale per i Documenti e gli Archivi dell'Oman.

Parole chiave: Autorità Nazionale per i Documenti e gli Archivi dell'Oman, Sultanato di Oman, uso scientifico, uso legale, uso pubblico, procedimenti archivistici 
Abdulmohsin Said AL HINAl: Archives and its Role in Preserving the Nation Memory: Legal and Scientific Use of the Records and the Role of National Records and Archives Authority in Oman as a Model, 197-208

Arhiv in njegova vloga pri ohranjanju spomina naroda: pravna in znanstvena uporaba arhivskega gradiva na primeru Nacionalnega arhiva v Omanu

\section{IZVLEČEK}

Zgodovina arhivov je zelo stara. Na tisoče glinenih tablic iz tretjega in drugega tisočletja pr. n. št. so našli v mestih, kot so Elba in Sirijo (2350 pr. n. št.). Ti arhivi so bili ključni za razumevanje starodavne pisave, jezika, kulture, politične in družbene strukture, ki je vladala v tem času. Arhive je že od petega stoletja dalje ustvarjala cerkev, in hranijo jih še danes. Ljudje so pričeli zapisovati svoje dejavnosti in dogodke v skale, na živalske kosti in kožo. Arhivi igrajo pomembno vlogo v spominu naroda. Pomembni so za organizacije, posameznike in skupnosti. Dajo in zagotavljajo nam dokaze in informacije o preteklih dogodkih in aktivnostih. Hranjenje arhivskega gradiva ima dolgo zgodovino $\mathrm{v}$ različnih civilizacijah, in arhivi nam posredujejo vrednote človeškega uma in razumevanje različnih dogodkov, kot npr. propada civilizacij, mejnih sporov, vojn, ki so zdesetkale prebivalstvo... Arhiv hranijo izvirno neobjavljeno gradivo, torej primarne vire. Ti zapisi so edinstveni. Če je arhivsko gradivo poškodovano, ukradeno ali izpostavljeno različnim nevarnostim, kot so vojne in teroristični napadi, so informacije, ki jih vsebuje, za vedno izgubljene. Arhiv je lahko neverjetno bogat vir informacij, ki jih je potrebno hraniti v skladu z zakonodajo in predpisi v korist osebja arhiva ali uporabnikov, in ki mora omogočiti znanstveno, pravno in javno uporabo ohranjenega arhivskega gradiva. Prispevek na kratko opisuje to uporabe na primeru prakse Nacionalnega arhiva v Omanu.

Ključne besede: Nacionalni arhiv, Sultanat Oman, znanstvena uporaba, pravna uporaba, javna uporaba, obdelava arhivskega gradiva

$$
\begin{aligned}
& \text { تَاريخ الارشيفات قديم جدا. الآلاف من الألواح الطينية تم العثور عليها برجع نَاريخها إلى قُبل }
\end{aligned}
$$

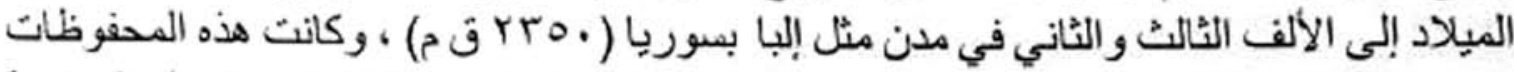

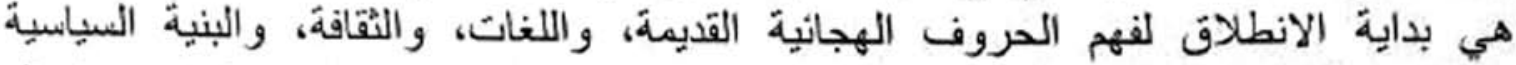

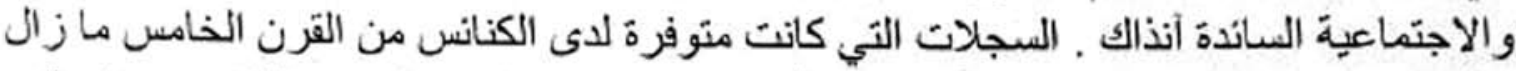

$$
\begin{aligned}
& \text { محتفظ بها حتى الوقت الحاضر لأهمبنها. بدأ الناس على تسجيل وتوثيق نشاطاتهم ومنامباتهج } \\
& \text { الخاصة بالكتابة في الصخور و عظام وجلود الحيوان. لذلك تلعب المحفوظات دورا هاما في }
\end{aligned}
$$

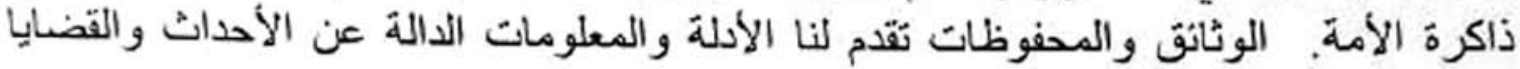

$$
\begin{aligned}
& \text { السابقة فهي اذن تهم الجميع سواء كان منظمات أو افر اد أو مجتمعات. }
\end{aligned}
$$

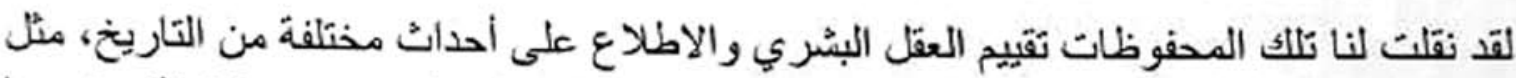

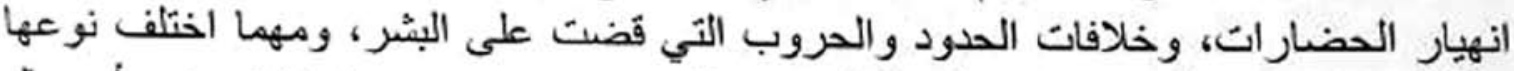

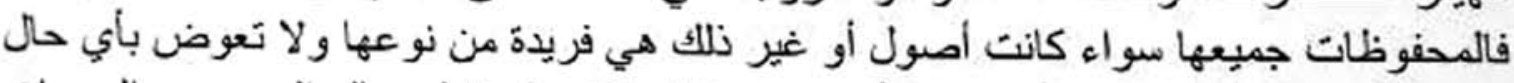

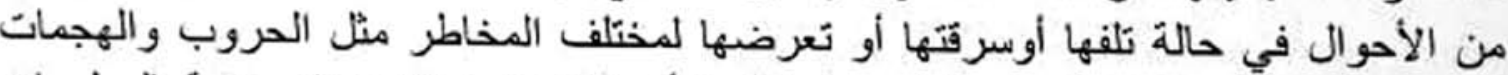

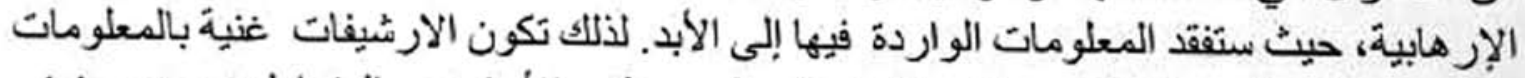

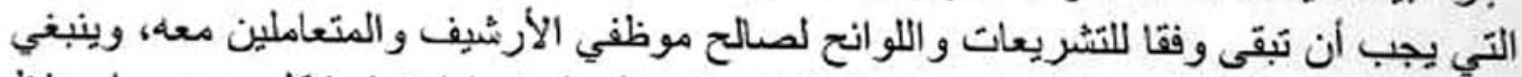

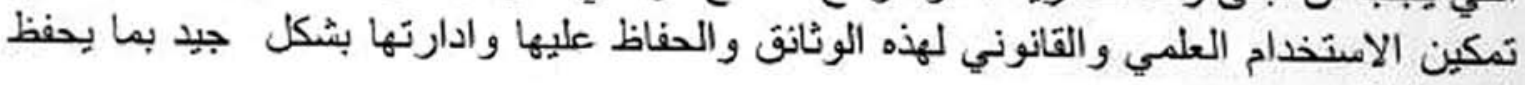


Abdulmohsin Said AL HINAl: Archives and its Role in Preserving the Nation Memory: Legal and Scientific Use of the Records and the Role of National Records and Archives Authority in Oman as a Model, 197-208

\section{Introduction}

The history of archives is very old. Thousands of clay tablets dating into to the third and second millennium B.C were found in cities such as Elba, Syria (2350 B.C.). These archives have been fundamental for understanding ancient alphabets, languages, culture, political and social structure prevailing in those time. Archives were established by the Church from the fifth century and are kept till nowadays. People started to register and record their activity and events, in the rocks, animal bones and skin. Archives play an important role in the nation memory. Archives and records are important for organizations, individuals and the community. They give and provide us an evidence and information about past events and actions. Record keeping has a long history in different civilization, and archives transfer to us the evaluation of the human mind and the understanding of different events during the history, like the collapse of civilization, boundaries dispute, wars that decimated the humans... Archives collect original unpublished material or primary sources; these records are unique and irreparable. If an archival record is damaged, stolen or exposed to various dangers such as wars and terrorist attacks, the information it contains is lost forever. Archives can be an incredibly rich holder of information that should be kept according to legislation and regulations in favour of the archive staff or its clients and should enable the scientific, legal and public use of preserved archival records.

This paper will describe in brief these uses and reflect to National Records and Archives Authority in Oman as example.

\section{Scientific use}

Archives as mentioned preserve the nation memory. They provide evidence of activities happened in the past. The scientific use in archival institutions represent the archives ability to organize and classify the archival material in order to be ready for use from public and archival institutions themselves.

Availability of records to researchers in physical and digital format, and their availability to public, are one of the main objectives of the activity of archives. It is not easy to deal with the collections in archives, moreover keeping records and save them in the clean environment in order to protect them from any infections that might infects documents is not an easy job to do.

Sterilization and restoration methods needed for the maintenance of records, are the main requirement for keeping the records in good condition and available for access and use by researchers. National Records and Archives Authority (NRRA) in Oman have good experiances in this process.

Health and safety program in archival process is essential, therefore necessary information is provided for employees, visitors and users. However, the information on how to deal with archival records should be clear and easy to understand. In each country the safety policy should be result of the Health and Safety Act, which requires employers to prepare a written statement of their general policy, organization and arrangements for health, safety and welfare at work.

\subsection{Database}

In addition to the daily work production carried out by archives institutions archives receive and collect many records and documents in physical as well as in electronic form. They are receiving and collecting data from variety of source, including business transaction, social media and others. These data are transferred in all type of formats like for example the structured and numeric data in traditional form to unstructured text documents, emails, videos, audio recordings and others. Archival database is a very important tool in the scientific use of archives. It is not only important how much data you have, but what the archives do with information technology and how the archive staff administrates these process to make the data available to the public and to themselves. When the archives are able to use and apply analytics to their big data they gain significant ground when it comes to managing their collections. There are many advantage to these data but because dealing with different sort of documents archives have to address also issues of transparency and privacy. 
Abdulmohsin Said AL HINAl: Archives and its Role in Preserving the Nation Memory: Legal and Scientific Use of the Records and the Role of National Records and Archives Authority in Oman as a Model, 197-208

\subsection{Access to records}

Enabling users to access the records in order to benefit in their scientific and cultural research is a priority of every archival service. Since archival records contain confidential records and civil statuses, archives should be very careful when making archival records available for users. Access to these records needs a high effort in organization and management of this aspect. To attract users archives offer downloads, share and re-use of archival records.

Today the internet and other social media are revolutionizing access and archives are exploring new technologies to increase public awareness of the range of available records. Archives have online searching possibilities, allowing computer and smart phone users through around the world to identify relevant records often by means of a simple keyword search. As archives collections are unique, the archivists in charge of caring for those collections strive to preserve them for use today, and for future generations of researchers.

\subsection{Organization of records}

Archives not only keep the historical records. A percentage of records on Governmental and companies' achievements are becoming a memory of the nation for the next generation. Therefore, archives institutions need to organize and manage this records to protect them from being destroyed. Specific guidelines for how people may use the records and how to protect them from any damage are prepared.

Since its establishment in 2009 NRAA is responsible for more than 38 governmental agencies. According to the Archival Act NRAA started to deal also with companies were the government share in their capital is not less than 25\%. NRAA works with individual government agencies separately in order to organize their private records. The private records means different functions from one agency to another. In this process we have to prepare nominal list of records and files and retention schedules to make agencies aware of when the files are transferred to intermediate repository, and when to migrate them to NRAA to keep it forever or for the destruction.

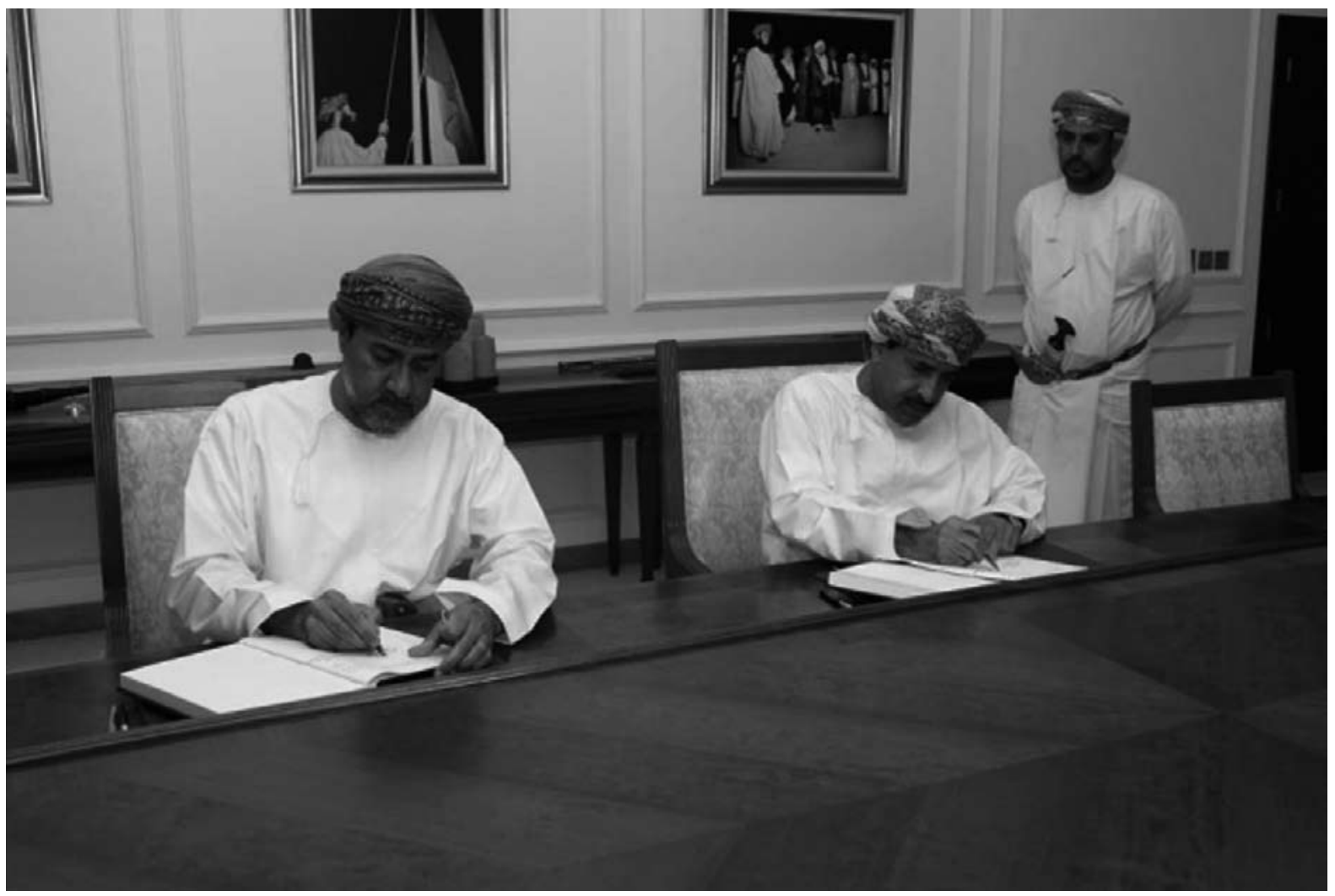

Image 1: Signing of an agreement between NRAA and Governmental agency 
Abdulmohsin Said AL HINAl: Archives and its Role in Preserving the Nation Memory: Legal and Scientific Use of the Records and the Role of National Records and Archives Authority in Oman as a Model, 197-208

\subsection{Restoration and sterilization}

Archives institutions keep the historical records as a part of the cultural heritage, and the conservation of such holdings is of vital importance. The conservation of archive materials is a skilful art confined before the development of modern processes to a small number of institutions throughout the world, and utilized methods dependent on the ingenuity and dexterity of the restorer. Although the intervention of science has led to a better understanding of the various causes and problems of deterioration and to the formulation of preventive measures, the use of orthodox methods and techniques has continued and is in all probability likely to continue. Conservation in NRAA contains of the chemical laboratory and automated laboratory, were the testing of solubility of ink is done and soluble ink is fixed as well as testing of PH/acidity of records, de-acidification of records affected with acid, removal of cello-tape from records using ethyl acetate in fume hood, or using methanol and ethanol are done. In automated laboratory leaf casting and cold section machines are installed. In this laboratory, fragile documents affected by insects, acid, torn in small pieces and those that have passed through the chemical laboratory are repaired through the leaf caster and sized on the cold section machine.

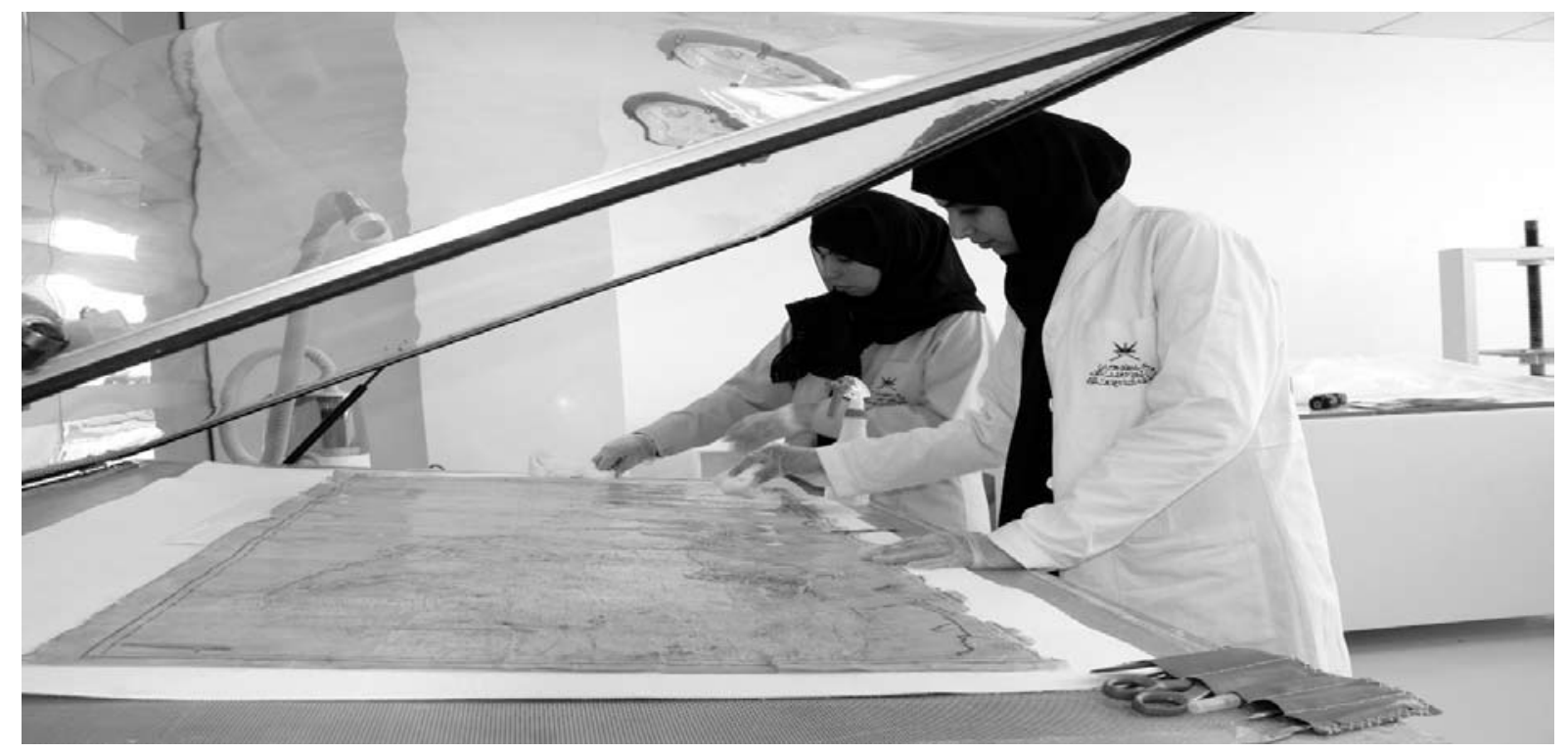

Image 2: Chemical treatment in NRAA

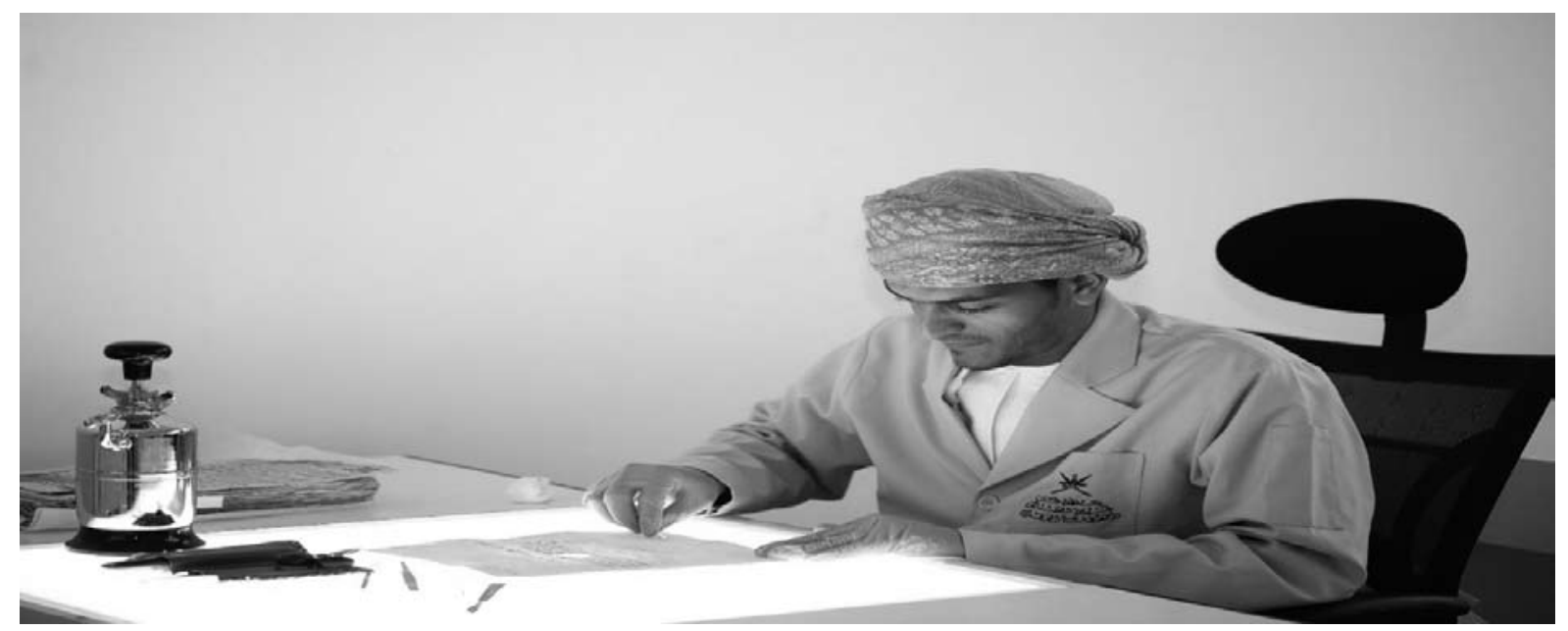

Image 3: Manual restoration in NRAA 
Abdulmohsin Said AL HINAl: Archives and its Role in Preserving the Nation Memory: Legal and Scientific Use of the Records and the Role of National Records and Archives Authority in Oman as a Model, 197-208

In the countries where the climate is variable and changing, unsuitable temperature and high humidity can cause fungi and bacteria that endanger the documents and destroy it. Therefore the extreme care through sterilization process is required to remove them from the documents in order to keep them for future generations.

This laboratory receives records which have just come to the authority, checks the presence of insects, bacteria and fungi infestation in the records and sterilizes them if found. The laboratory has various modern machines. This modern system is followed in Sultanate of Oman from creation of records to their migration to archive and for its operation the implementation of ISO standards is required.

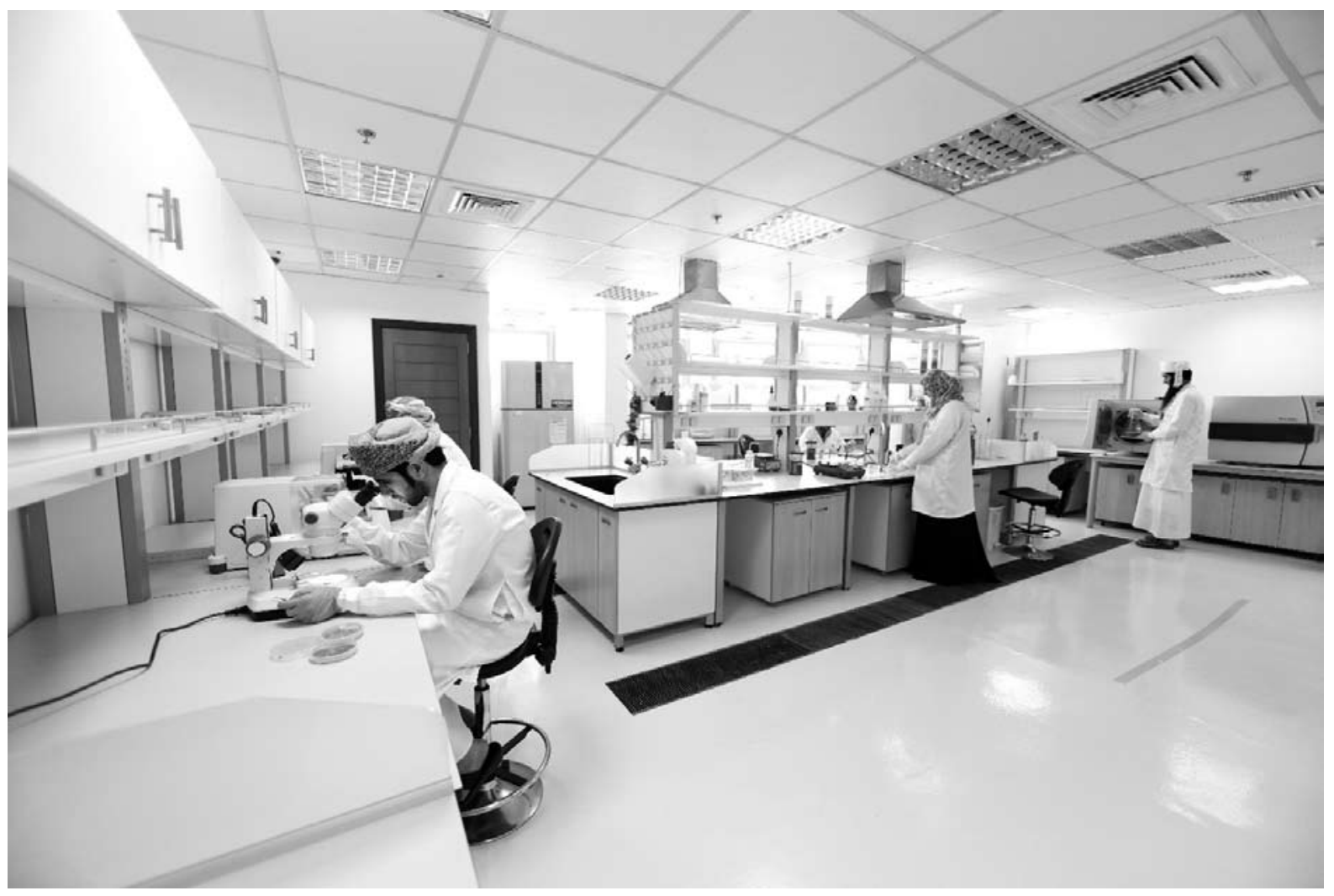

Image 4: Biology Laboratory in NRAA

\subsection{Microfilm and digital format}

"Microfilm is the automated photographic process of copying documents onto film at a reduced size". The historical records and other archival material needs to be keep forever, thus such a preservation demands more space. Circulation of such original and valuable documents in the reading room is worrying and not recommended by archives. The best way to use such a documents is to us them in the form of microfilm or other digital format. Microfilm plays an important role in saving records for long time, presumably for 500 years, without any changing of format. However, in many archives nowadays microfilms has become unwanted because of high cost of operation. Many types of microfilm, including $16 \mathrm{~mm}$ roll film and $35 \mathrm{~mm}$ roll film, are used for the archival conservation of A4 size documents to A0 drawings. In 2009 NRAA established the microfilm section which is now becoming one of the most important departments within NRAA. This section is outfitted with a modern equipment and conserves nowadays thousands of historical records and manuscripts. 
Abdulmohsin Said AL HINAl: Archives and its Role in Preserving the Nation Memory: Legal and Scientific Use of the Records and the Role of National Records and Archives Authority in Oman as a Model, 197-208

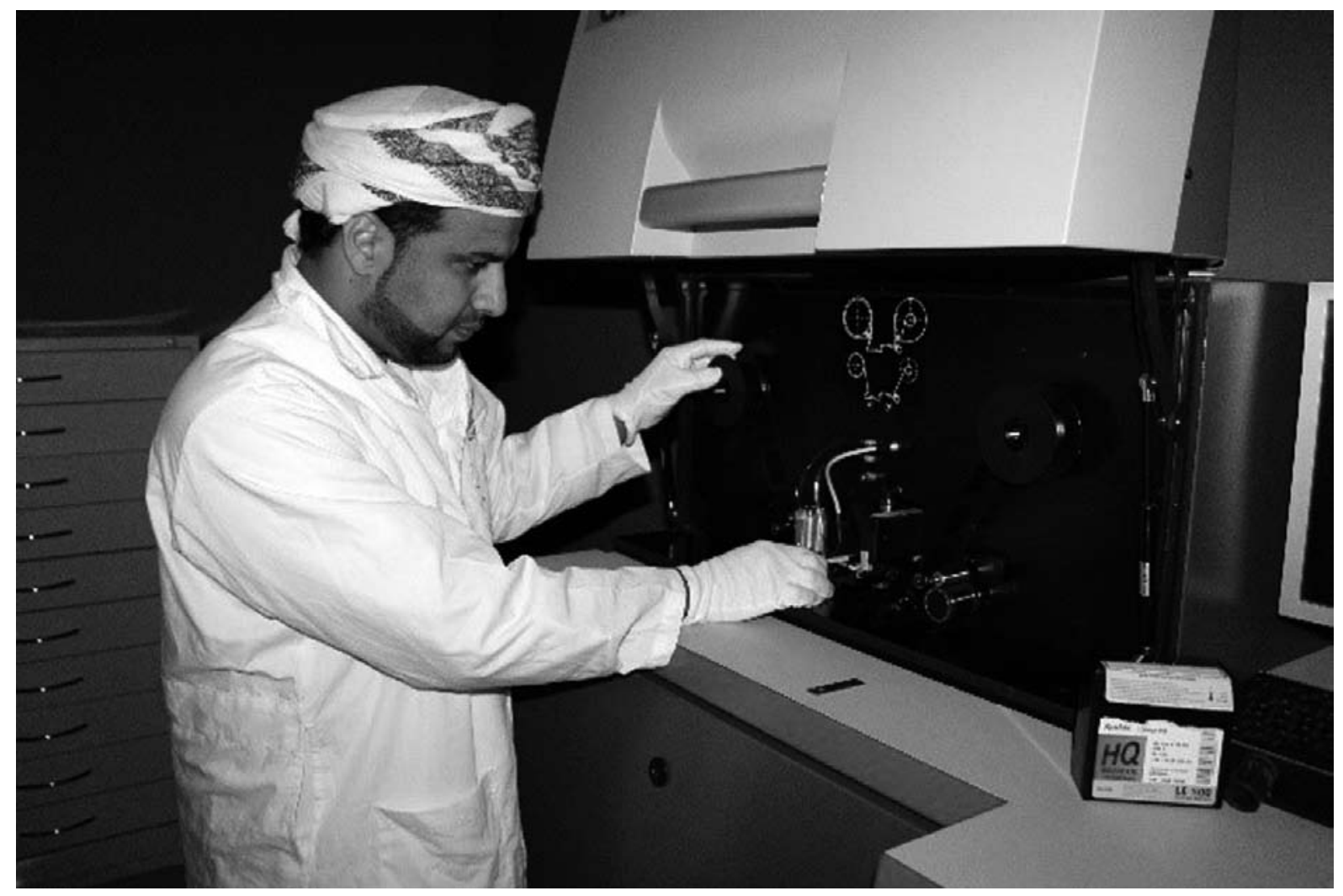

Image 5: Microfilm laboratory in NRAA

"Digitalization allows the archivist to make information from the archives holding widely available either through the creation of electronic databases of digitized archival records or through the design of the thematic virtual exhibits" (Millar 2010).

Digitization presents many preservation challenges. Archival records are at risk of being lost due to the rapid development in computer hardware, operating system and application software, with short effective life of most physical storage media. Archives should develop a digital preservation methodology, supported by software, to ensure that the important digital records are preserved.

In the digitization process NRAA established "Electronic Documents and Records Management System - EDRMS" project. The EDRMS is defined as an automated system whose primary purpose is to manage all the electronic documents and records of any organization throughout their entire lifecycle. The system must be a hybrid system - capable of managing both electronic records as well as physical records (according to the two national guidelines mentioned above for the management of electronic and physical records). 


\section{LIFECYCLE OF RECORDS}

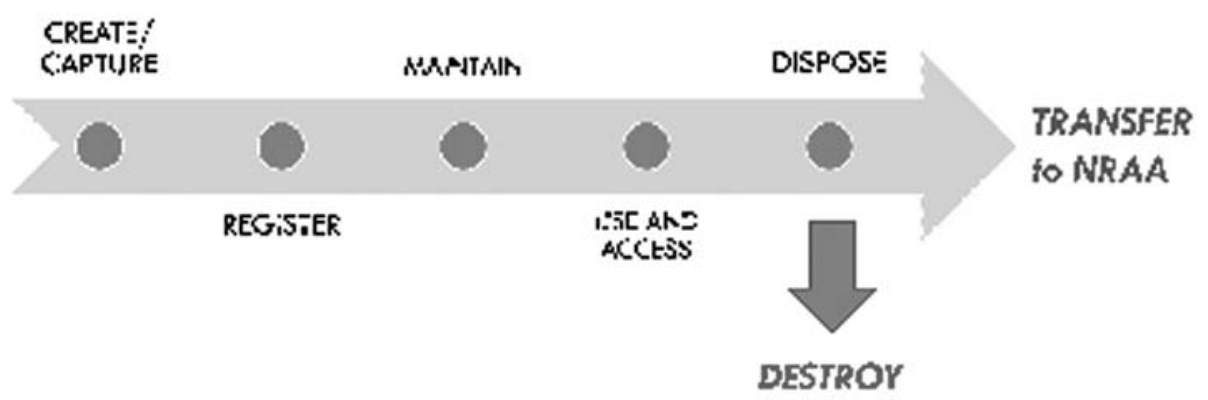

Image 6: Records Lifecycle from the NRAA EDRMS project

Government agencies within Oman are required to transfer part of their official records (estimated between $4 \%-7 \%$ depending on the agency) to NRAA as permanent archives (i.e. to be kept forever in NRAA), and the rest to be destroyed after specified retention periods. Which type of records to transfer/destroy and how long should they be retained at the agency before they are transferred/destroyed is specified in policies (i.e. business classification schemes and retention schedules) that are carefully drawn up for each government agency and approved by NRAA.

In order to be sure that the government agencies' records which are transferred to NRAA as archives are complete, unaltered and possess the characteristics of authenticity, reliability, integrity and usability, NRAA has to ensure that the records at the government agencies are managed correctly right from the beginning (i.e. the moment they are received or created at the agency) until they are destroyed or transferred to NRAA. The benefit and key objective of the project is as follows:

- To improve good governance and accountability at NRAA and the various government agencies by ensuring that the evidence of business transactions and service fulfilments (i.e. records) are managed correctly to ensure its authenticity, reliability, integrity and usability.

- To ensure that the management of records is compliant to the standards and guidelines set by NRAA, and other applicable legal or financial regulations.

- To secure the records at NRAA and government agencies from unauthorized access and prevent instances of tampering, corruption, leaks and the disappearance/loss of such records, and to meet business needs of NRAA and the government agencies for highly available, reliable, scalable and secure EDRMS.

- To migrate the existing data to the new platform while meta- tagging the migrated data.

\section{Legal use}

To organize archive process legally the privacy and ethical use have to be respected. Archives are important resource for answering questions about the past. Rerecords may be used to settle legal, claims, they may clarify family history. Therefore copyright, privacy policy and records copying must be regulated.

\subsection{Privacy and ethical use}

Privacy refer to an individual's right to be free from or intrusion or interference by others' (Panel on Research ethics, 2016). Archives must look beyond legal destruction and consider the ethics of privacy and access. Archives must balance between the right of researches to access the records and use personal information and the right of the people. Archives keep the records in order to use them, however, 
Abdulmohsin Said AL HINAl: Archives and its Role in Preserving the Nation Memory: Legal and Scientific Use of the Records and the Role of National Records and Archives Authority in Oman as a Model, 197-208

they must consider the personal right. In Archives researchers may seek to collect documents, share and access different types of information about the social life of people or inventions and use this information for purposes outside the research. In NRAA the private information related to people and their social and health life is accessible, as identified by law, only after hundred years. The ethical concerns regarding privacy decrease and it becomes more difficult or impossible to associate information with a particular individual. These concerns also vary with sensitivity of the information and the extent to which access, use or disclosure may harm an individual or group.

\subsection{Improvement of legislations in archives environment}

Archives keep records from hundred years or more. Many Archives are keeping record in bad environment, especially those which do not have enough budget to build a modern repository. Therefore, those records are infected from bacteria and fungi. Archives should enact legislation that provides healthy and safety working environment. Archives as public facilities protect many collection regarded as cultural and historical heritage. Business location and working environment in archives not only pose a challenge for the staff, visitors, researchers, and students using archives, but also archival records. Archives should intend to fully comply in all respect with all legal requirements to ensure the health, safety and welfare of all staff and visitors to the archives building. Staff and visitors must be informed of any changes in health and safety legislation, notifications have to be available in clear place and send to the employees by email, as well as addition seminars must be organized.

\subsection{Health and safety}

As mentioned health and safety is essential in archival process and for archives employees, visitors and users. Health and safety booklet must be easy to understand and the Archives should update the awareness of employees and clients in regularly in order to follow any new modifications that have taken place. In NRAA employees must sign the health and safety requirements when appointed. Any offence from staff will be investigated and action will be taken. Health and safety regulation must clarify the duties of employees, visitors, contactors, members, and anyone else. Health and safety regulation describes the working place in archives and risks. Description of working place such as working with computers, manual handling, lifting, carrying and moving records inside the archives and from the governments agencies, using archive materials, working with chemicals and using chemical is given.

In addition, clear instructions are given in front of some restricted areas such as labs and microfilm workshops.

Many Archives follow this process by establishing health and safety handbooks and the employees must read this hand book before join the archives. For example, the National Archives of Scotland issued Health and Safety Handbook and published it in 2002, giving the employees the essential health and safety information for everyone working in the archives or dealing with it. The information includes safety policy which is in accordance with Health and Safety Act, workstation design, dealing with computers, manual handling assessments, lifting method and carrying and moving records.

\subsection{Awareness}

Awareness in the archival process, especially the one of employees and public, is very important. The awareness consists of information and discussion on archival and records management, restoration and conservation. This awareness should include staff, researchers, and students at all levels. Also nongovernmental agencies must know and follow this process. Awareness is important for all those mentioned in order to know and avoided any mistakes that may occur from staff and those dealing with archives. The awareness of the staffs means they should know their duties and should not enter the restricted areas such as repository, labs, IT storage and others. For public the awareness means to respect the organization policy in archives and following of the instructions in the building. 
Abdulmohsin Said AL HINAl: Archives and its Role in Preserving the Nation Memory: Legal and Scientific Use of the Records and the Role of National Records and Archives Authority in Oman as a Model, 197-208

\subsection{Copyright}

Users may re- use archive documents or copy information from website or re-use the documents for commercial purposes after using them for research. Serious violations could be prosecuted if the law is broken. In NRAA, a stakeholder may acquire copies that are certified for their authenticity by archives. These copies and contents must have the same legal value as the originals. Any person allowed to access the archive in accordance with the law may obtain copies, photos or contents of such archives at their own expenses. However they cannot use obtained documents for commercial purposes without written consent from the archive, and every person who access the archives due to its work shall not use them beyond the scope of the provisions of the law and regulations.

\section{Public use} mation.

Public use of archives consists of a researcher services, exhibitions, publications, visits, and infor-

\section{Access to archives}

Access to archives allows public to access information in the records weather in its physical or electronic form, maps and audio-visual records and to use archive facilities. Many archives offer telephone information and answer email enquiries to respond to the needs of researchers. Researchers can request the reproductions of the documents for their research in both format digital or physical. The majority of researcher services is concentrated in the reading room, and for visiting this room, users need to fulfil special requirement before entering. The reading rooms and other facilities guidelines which include the opening time and what researcher should bring with must be given to the researcher prior to use of archives. New Zealand archives put the reading room guidelines in their website. They include information like the opening times, the list of allowed and prohibited items in the reading room, copying and publishing instructions. In the United Kingdome archives the researchers should spend five minutes to read the instructions for the reading rooms and accept them. Following the instructions in NRAA reading room is mandatory before entering into reading room.

\subsection{Exhibitions}

Exhibitions play a major role in archive business. They are more common in museum environment than in archival institutions. Exhibition traditionally involve the temporary deposit of physical archival object for the purposes of display. There are different types of exhibitions such as:

- Educational exhibitions, prepared for students in the Universities, collages and schools, in order to promote the knowledge about archives and to show the achievement of the country.

- Records exhibitions, related to the historical, educational, intellectual and artistic achievement of the country. Usually these kind of exhibitions are held in the exhibition centres, and sometimes they are moving from region to region.

NRAA annually organizes at least nine exhibition, but the main exhibition is held in November every year. These exhibitions attract brother public, including students, families, disabled people etc.

NRAA is also organising exhibitions in co-operation with some archives around the world. We already organized guest exhibitions in National Archives of France, Turkey, India and Tanzania. 


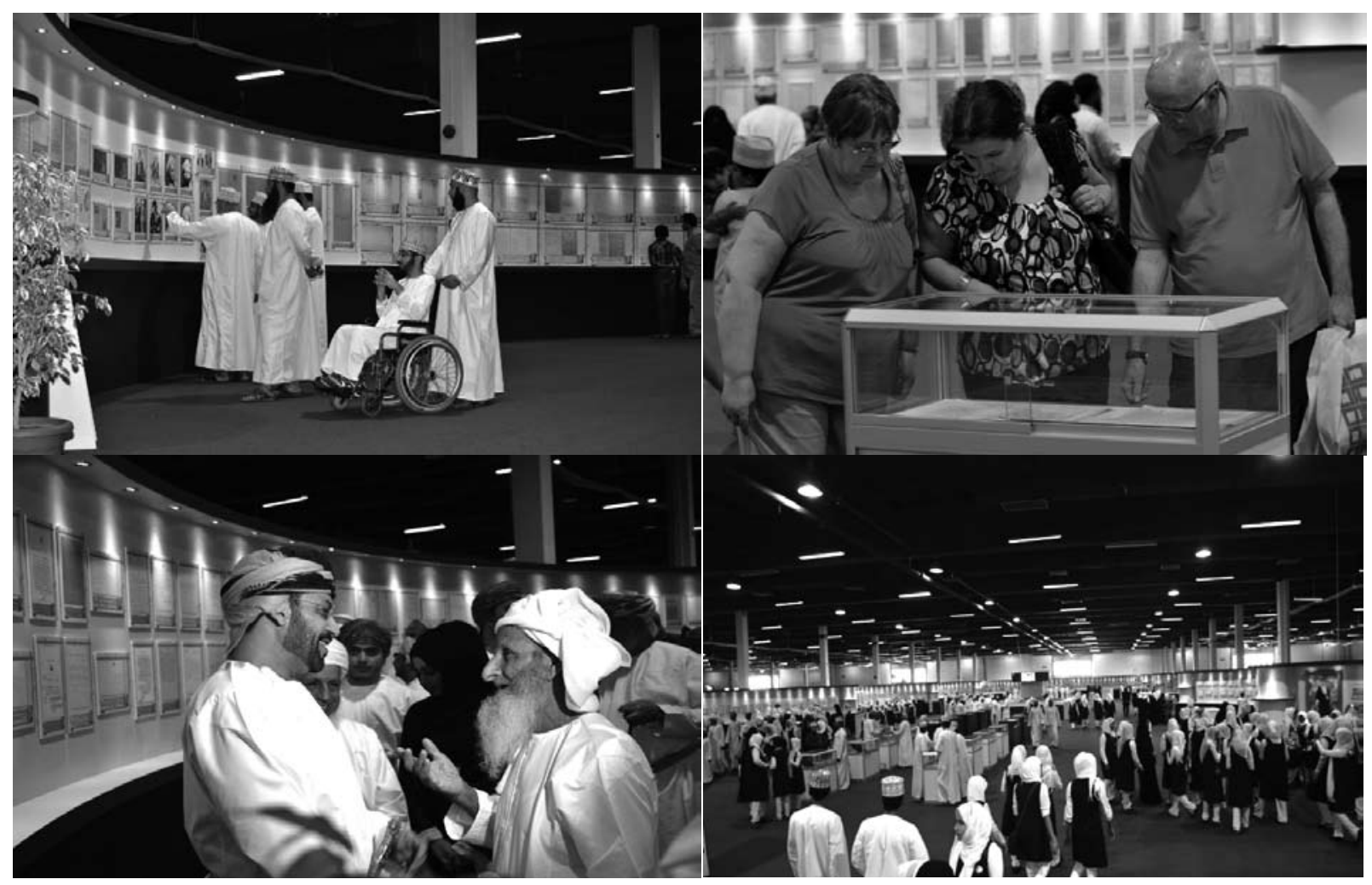

Image 7: Different type of visitors attracted by exhibitions organised by NRAA

\subsection{Publication}

Publication, for instance, is generally considered non-archival. They are deliberate creations, intended for dissemination and use. However, archival publication we ate talking here about provide information on the National Archives and its holdings, and also include works on professional archival practices and scholarly works on people and events of historical interest. Many archives obtain their publications online or in print, and some of them free of charge.

Despite of the profound changes in publishing brought by technology, many of us believe that archives publication is important for the future. Archival publications are highlighting what is available in archive documents and are encouraging people's knowledge and the public use of archives.

\section{Conclusion}

Thousand millions of records about people, events, decisions and governments achievements built the history of our nation. Recorders and kept archives are that small portion of all the information, communication, ideas and opinions people generate. Archives, weather physical or digital, are tangible. Daily thousands of people login in archives systems around the world and this huge information flows rapidly between researchers and archives institutions. Archives must organize and arrange their business operation procedures to meet the requirements of dealing with archives and to keep the records in right and save way. Scientific uses in archives means to provide and manage a huge database, in order to save and allow access to the information, images, audio-visuals, maps etc. When organizing the system of access to those materials, archives in the same time have to consider the process of health and safety for their employees. Because they are dealing with old documents they might be infected with dust, bacteria etc. Dealing with any type of risk led us to work on legal use through the implementation of the law and regulation for the uses and employees. Legal use of archives involves the privacy of information and ethical issues. At the same time working environment must be clear and everybody has to understand its needs. Access to records, exhibitions and publications are archives obligation toward the public in order to inform brother audience about the availability of the records related to the memory of the nation. Archives represent a source of information and reference key to the nation memory. 
Abdulmohsin Said AL HINAl: Archives and its Role in Preserving the Nation Memory: Legal and Scientific Use of the Records and the Role of National Records and Archives Authority in Oman as a Model, 197-208

\section{Used bibliography}

Millar, Laura A. (2010). Archives: principles and practices. London: Facet Publishing.

Fox, Lisa L. (1978). Reservation Microfilming, A guide for Librarians and archivists, second edition.

Yahya Yai, Abdullah (2015). NRAA EDRMS project guidelines.

Privacy and Confidentiality (2015). Available at http://www.pre.ethics.gc.ca/eng/policy-politique/initiatives/ tcps2-eptc2/chapter5-chapitre5/ (accessed April 2016).

Panel on Research Ethics (2016). Available at www.pre.ethics.gc.ca (accessed April 2016).

Health \& Safety Handbook - National Archives of Scotland. Available at http://www.nas.gov.uk /documents/ hsHandbook.pdf.

http://www.microfilm.com/an-introduction-to-microfilm/reservation

Archive Principles and Practice: an introduction to archives for non-archivists (2011). Available at http://www. nationalarchives.gov.uk/documents/information-management/archive-principles-and-practice-an-introduction-to-archives-for-non-archivists.pdf.

Schmidt, L. (2016). Using Archives: A Guide to Effective Research. Available at http://www2.archivists.org/usingarchives\#.VzGnO4R95D8 (accessed April 2016).

Typology: 1.04 Professional Article

Submitting date: 01.02.2016

Acceptance date: 20.02.2016 